ISSN No. 0974-035X

An Indexed, Refereed \& Peer Reviewed Journal of Higher Education

Towards Excellence

UGC-HUMAN RESOURCE DEVELOPMENT CENTRE,

GUJARAT UNIVERSITY, AHMEDABAD, INDIA

\title{
E-BOOKS IN ACADEMIC LAW LIBRARY: AN OVERVIEW OF THE USERS' REQUIREMENT AND CURRENT SITUATION
}

\section{Dr. Atul Bhatt}

\begin{abstract}
:
The advancement of latest ICT based technology in publishing has brought the attention of law librarians to rethink the current practices of collection development and need to focus on uses' needs and make appropriate steps to develop library resources towards conventional resources / non conventional resources. Now-a-days users' perceptions on e-resources are well known in academia. This paper is case study of academic law library which examined the current situation of E-books and the users' expectation of towards E-books at Library Resource Centre, Institute of Law, Nirma University, (ILNU Library). ILNU Library is subscribing more than 13 online databases and some of database provides access of E-books. Users' survey has been conducted to hear valued ILNU Library users' on their expectations towards library resources and services and based on study suggestions recommended. The results and suggestions of this study will be useful for Law Librarians in their collection development.
\end{abstract}

\section{Keywords: E-books, Law Library, Online Resources}

\section{Introduction:}

An Academic Law Library is quite different by its content, management, organization and users' needs. The fast evolving concept of law affects everybody; in this fluid scenario collection development is very important area for the professionals working with legal information centers. To provide right information with quick response is basic requirement of law librarians. Legal professionals like practicing lawyers, law students, law teacher, Legal researcher, an attorney, judges, policy makers and government officials are basically dependent on prompt information services. This is the only profession where each professionals are having their own sound libraries Tice, Beatrice A (2011) has mentioned from American Bar Association that "It is a basic principle of legal education that the law library is the heart of the law school ..." at the same time According to Bar Council of India (2010) "It is often said that Science students learn mostly by doing in the laboratory and law students have to learn in Library by way of reading." The 
academic Law Library is far more than a research center where students and faculty come to study and to find information. To keep a tuning with latest technology and to provide right information to right person in a right time to add e-books in a collection is need for the hours for Law libraries.

During recent years various studies have been carried out which have demonstrated the importance, the increase in use and the progressive penetration of E books in the University and Research Centre. This progression can be possible due to Fast of access, updation at regular interval, storage capacity, low costs (in distribution only not in other areas such as production, marketing, etc.), connectivity, space saving, portability or the possibility of access anywhere, anytime among other advantages. The E-book is beginning of significant work both in the classroom and distance learning, as well as in research activity.

\section{Literature Review}

Alison Taylor (2007) describe how an E-books project was set up at the University of Worcester Information and Learning Services with the aim to improve user access to the range of textbook materials available in his Article " E-books at the University of Worcester: a case study" Rojesky, Mara (2012) study found a much higher use of E-books over print reserves. The survey and focus group responses also found a relatively high student satisfaction with the use of E-books, despite some reported use problems further also stated that replacing traditional reserve materials with E-books offers a perfect opportunity to transform low use items into tools for student success while making better use of our collections funds. O'Gready Jean (2012) has mentioned that the reading public has widely embraced eBooks, but their future in law firms remains unclear. The success of eBooks likely will hinge on a close collaboration of law librarians and legal publishers. It will take time, but the right platform with the best workflow at the right price could be a "win-win" for law firms and legal publishers. Rai, Priya. (2015) have studied National Law University, Delhi and depicts detailed experiment carried out to weave e-books into library catalogue through LIBSYS-7. Effort is done to integrate e-books with print book catalogue through library automation software to collocate search results. Yatin Talati and Bhatt, Atul (2016) observed that that most of ILNU law students found library resources according to their expectation and users overall assessment on print and online resources depicts that online resources are very sound but need to add more E-books. Bhatt, Atul (2018) observed that traditional concept of access to resources is replaced with emerging electronic resources and it is preferred by academia and law libraries. E-books are valued resources for law libraries having bright 
prospects and increasingly popular in academic law libraries.

\section{The Legal Research Library for the $21^{\text {st }}$ Century}

An Academic Law Library is also known as Legal Research Library as many users' of library are participating in various Moot Court Competitions at national and international levels and conducts their legal research from the library. As an academic Law Library, the ILNU Library has a vision and mission that is easy to state and hard to define: our vision is Empowering Legal Research and Learning community in ILNU with deep expertise, innovative services, and outstanding collections strengthened by strategic management at the same time we are on the mission to provide wide-ranging legal resources and services in support of the legal research, teaching, and learning needs of the Users Community and to provide an essential component of the teaching, legal research, and learning activities of the Institute. The Library only fulfills its mission through a variety of innovative services and legal resources that are developed and refined by expert Library Professionals in collaboration with the active Library Users Community: the students, faculty, and staff. As an Academic legal Research Library, our mission deepens and broadens with open and equitable access to essential information for legal research and scholarship etc. and we strive to be the leading model of the $21^{\text {st }}$ century Academic Legal Research Library. To fulfill our mission requires near constant change, as technological requirements, newly updated resources, professional skill etc.

\section{About E-Books and Definitions}

E-Book is a book in electronic format. It is downloaded / Accessible from a computer, PC, Mac, laptop, PDA, tablet, smartphone or any other kind of reading device, and is read on the screen it is an electronic version of a traditional print version of book that can be read by a personal computer or an eBook reader. The word E-Book is coined by Van Dam during 1960s.

According to Oxford English Dictionary 'an electronic version of a printed book which can be read on a computer or special hand-held device.' A the same time Armstrong, Edwards \& Lonsdale defined e-books as 'any piece of electronic text regardless of size or composition (a digital object) but excluding journal publications, made available electronically (or optically) for any device (handheld or desk-bound) that includes a screen.'

\section{Mode of Acquisition and Access/Ownership}

E-book possession is always not the owner but they will be licensees. Unlike the owners of a physical book, they can't have the unlimited right to lend an e-book, give it away, resell. If it's bought for their iPad, they won't be able to read it on their Kindle. And if Amazon or the other 
sellers don't like what they've done with it, they can take it back, without warning.

1 Aggregator Subscription Packages

2 Publisher-direct subject specific Package Purchase

3 Short Term Loan (subscription based)

4 Demand-Driven Acquisition

5 Patron-Driven Acquisition

6 Evidence based selection

7 Title-by Title purchasing

8 Subscription of E-books database

\section{Significance and advantage of E-Books}

E book have made the task easier to publish any kind of information. Computer users can have access to E-books on any system with different configuration. They can easily open and view the digital books on the computer system and the original format does not change. Low update cost, Multimedia format and searchable capability which provides to quickly jump to the interesting page. If they create the digital book in an appropriate format, they can easily reduce the size of the file. Therefore, one can accommodate more than hundred pages in the electronic book. It is also easy to store and carry the digital book in portable devices like pen drive, Digital Video Disc or iPod.

\section{Importance of E-Books:}

E-books can be use for promoting online business. An entrepreneur can write informative or promotional content towards the company website. This enables to promote the products and services online and build favorable company reputation. Additionally an e-Book can carry thousands of pages. One can make available any kind of information on the Internet through electronic books. Even Authors can contribute their work online like poems, novels, fiction stories, rhymes etc. And also they can also receive feedback from the readers for their work on the Internet.

\section{Open Access E-Books}

In recent Era many Blogs and even Publishers are giving Links for the Open Access E-Books. E.g. University of Leicester - on its page for Digital Library following list can be seen. Taylor and Francis offers some of the excellent E-books Open Access. Apart from that Project Gutenberg, Internet Archives, The online book page, Open Access Publishing in European and Directory of Open Access Books are major initiatives for open access E-books. 


\section{Various Law E-book publishers}

Various well-known law book publishers are also providing E-books with subscription or procurement model they are:

1. Hart Publications

2 Oxford University Press

3 Hein Online

4 Edward Elgar publishing

5 LexisNexis

5 Taylor and Francis

6 Cambridge University Press

7 Walters Kluwer

\section{ILNU Case Study}

Bhatt, Atul (2014) his study depicts that most of law faculty members preferred to use Information and Communication Technology-based library resources in comparison to print resources and most of law faculty members have reported that the Internet has expedited the research process; thus, overall dependency on Internet access has increased.

At the same time we have carried out Students feedback (User Survey) in 2016 and we have found that $71 \%$ of library users have replied that online resources are more preferred in comparison of conventional resources. At the same time after provided a trial access of trial access of E-Books databases like E-brary by Proquest and EBSCO E-Books we have asked more than 125 users for their feedback and found that out of them $63 \%$ of respondents replied that they need any one online E-books database for their legal research. When we have asked the what kind of resources you seek in your library we found that $65.3 \%$ of respondents have replied that they always seeking online resources followed by $32.1 \%$ of respondents replied they mostly seeking more print in ILNU Library. We have also asked that how often you access E-books from our subscribed online databases $61.2 \%$ respondents replied that they usually used online resources to access E-books followed by $31.1 \%$ replied for some time. Now-a-days E-books are also available in open access domain and we have asked about awareness on E-books from open access domain $51.3 \%$ of them replied that they rarely used E-books from open domain.

\section{Suggestions:}

To focus on above both Sayings and to develop Analytical and Legal Research Skill in Emerging Scholars of the Institute and assist them in Legal Research, ILNU Library should plan to procure 
some of the more significant E-books related to Law from various publishers in ILNU Library to provide Library Services more excellent way.

Most of law student prefers online resources in comparison to print resources, most of them have stated that they have very good computing skills. This use may be due to availability, advancement and promotion of legal e-resources. This study also revealed that most of law students prefer to access information/judgments from license online resources in compared to open domain resources. This study also reflects that now a days library user prefers online resources in compared to conventional/ print resources and to serve our user community in better way Library also need to add more E-books and E-books databases.

\section{Conclusion:}

According to O'Gready Jean (2012), the success of eBooks is based on a close collaboration of Law Librarians and legal publishers. It will require open mindedness and creative thinking on both sides. Some time make taken for this new scenario - but the right platform with the best workflow at the right price could be a "win-win" for law firms and legal publishers - and result may be Library area - "the size of a phone booth."

With the understanding, what a research law library is, what should be in a research library, and what functions a research library fulfills - actions should be followed towards what 21 st century Academic Research Library requires. And also focus on how these all components will become possible in the coming years. The ILNU Library believe to collect, preserve, and provide access to information, in whatever form or medium that information may come.

Law Librarians have enormous challenges as E-Readers and E-books become more accepted and popular in this Tech Era. To keep tuning with young minds, emerging new developments should be applied and has to loosen up tradition. To look forward and meet the user's expectation for providing high quality Library services, we should start to procure e-books as well as library has to create awareness among the library users on various open access platform which are providing E-books. 
Towards Excellence: An Indexed, Refereed \& Peer Reviewed Journal of Higher Education / Dr. Atul Bhatt / Page 67-73

\section{References:}

Armsrtong,C.J.; Edwards, L. \& Lonsdale, R. (2002) Virtually there: E-books in UK academic libraries. Program: Elect. Lib. \& Inf. Sys. 36(4), 216-27.

Bar Council of India (2010) Bar Council of India (BCI) Manual. New Delhi: Bar Council of India, 34.

Beatrice A. Tice American Bar Association, Factors Bearing on the Approval of Law Schools, cited in Glen Peter, Ahlers (2002). The History of Law School Libraries in United Status. New York: William S. Hein \& Company

Bhatt, Atul (2018). A modern Law Library Action: the future of Digital Books in Indian Law Schools. International Journal of Allied Practice, Research and Review, 5(1). 1 - 5.

Bhatt, Atul Ashokbhai (2014). Information needs, perceptions and quests of law faculty in the digital era. The Electronic Library, 32 (5). 659 - 669.

Soanes, C. \& Stevenson, A. (Ed.) (2008) Oxford English Dictionary, Ed.11. New York: Oxford University Press.

Mara Rojeski, (2012).User perceptions of ebooks versus print books for class reserves in an academic library. Reference Services Review, 40(2), 228 - 241.

Talati, Yatin \& Bhatt, Atul (2016). Effective Marketing Strategy of ILNU Library Service, Resourcesand Products: Special Reference to International Law Resource Centre. International Journal of Library \& Information Science, 5(3), 91-98.

Taylor, Alison (2007). E-books at the University of Worcester: a Case Study. Program, 41 (3), 217-226. retrieved from https://eprints.worc.ac.uk/543/

O'Gready Jean (2012). The Future of ebooks in Law Firm and Future of Libraries. Practice Innovations : Managing in a changing legal environment, 13(3), 13-15.

Rai, Priya, Bakshi, Samar Iqbal \& Singh Akash (2016). Weaving E-books in Library Collection: An Experience of National Law University Delhi, India" DESIDOC Journal of Library \& Information Technology, Vol. 36, No. 1, pp. 5-9

\section{Dr. Atul Bhatt Associate Professor \\ Department of Library and Information Science Gujarat University Ahmedabad}

